\title{
Kudzu (Pueraria montana) community responses to herbicides, burning, and high-density loblolly pine
}

Timothy B. Harrington

Corresponding author. USD A Forest Service, Paci ${ }^{\circledR} \mathrm{C}$ Northwest Research Station, 3625 93rd Avenue Southwest, Olympia, WA 98512-9193;

tharrington@fs.fed.us

Laura T. Rader-Dixon

9915 Klaus Circle, Richmond, VA 23060

John W. Taylor, Jr.

USD A Forest Service, Southern Region, Forest Health Protection, 1720 Peachtree Road, NW, Atlanta, GA 30309

\begin{abstract}
Kudzu is an aggressive, nonnative vine that currently dominates an estimated 810,000 ha of mesic forest communities in the eastern United States. To test an integrated method of weed control, abundances of kudzu and other plant species were compared during $4 \mathrm{yr}$ after six herbicide treatments (clopyralid, triclopyr, metsulfuron, picloram 1 2,4-D, tebuthiuron, and a nonsprayed check), in which loblolly pines were planted at three densities $\left(0,1\right.$, and 4 seedlings $\left.\mathrm{m}^{2}{ }^{2}\right)$ to induce compe tition and potentially delay kudzu recovery. This split-plot design was replicated on each of the four kudzu-dominated sites near Aiken, SC. Relative light intensity (RLI) and soil water content (SWC) were measured periodically to identify mechanisms of interference among plant species. Two years after treatment (1999), crown coverage of kudzu averaged , $2 \%$ in herbicide plots compared with $93 \%$ in the nonsprayed check, and these differences were maintained through 2001, except in clopyralid plots where kudzu cover increased to $15 \%$. In 2001, pine interference was associated with 33,56 , and $67 \%$ reductions in biomass of kudzu, blackberry, and herbaceous vegetation, respectively. RLI in kudzu-dominated plots (4 to 15\% of full sun) generally was less than half that of herbicide-treated plots. SWC was greatest in tebuthiuron plots, where total vegetation cover averaged $26 \%$ compared with 77 to $111 \%$ in other plots. None of the treatments eradicated kudzu, but combinations of herbicides and induced pine competition delayed its recovery.
\end{abstract}

Nomenclature: Clopyralid; 2,4-D; metsulfuron; picloram; tebuthiuron; triclopyr; highbush blackberry, Rubus argutus Link. RUBAG; kudzu, Pueraria montana (Lour.) Merr. PUEMO; sand blackberry, Rubus cunefolius Pursh RUBCU; southern dewberry, Rubus trivialis Michx. RUBT R; loblolly pine, Pinus taeda L. PINTA.

Key words: Integrated weed control, invasive weeds, interference, crown cover, biomass, light intensity, soil water.
Kudzu is a semiwoody, nitrogen- ${ }^{\circledR}$ xing vine native to subtropical and temperate regions of C hina, Japan, and Korea (van der Maesen 1985). From 1920 to 1950, it was planted throughout the southeastern United States on about 1 million ha to control erosion and to provide livestock forage and shade (Bailey 1944; Mitich 2000). Because of the rapid elongation of its twining vines (up to $30 \mathrm{~cm}$ per day and $18 \mathrm{~m}$ per year) and the ability to overtop and kill other plant species (Everest et al. 1991), kudzu is considered one of the most invasive weed species in the United States, with an estimated coverage of 810,000 ha (Corley et al. 1997). Forestry problems associated with aggressive vines such as kudzu include mortality of edge trees, exclusion of native plant species, and potential to increase ${ }^{\circledR}$ re hazard during winter (Putz 1991). Because of these concerns, the U.S. Congress listed kudzu as a federal noxious weed in July 1997.

A variety of plant characteristics are responsible for the invasiveness and tenacity of kudzu. The semiwoody roots of a single plant can have diameters of up to $30 \mathrm{~cm}$ and extend to depths of $3.7 \mathrm{~m}$ (Miller 1988; Miller and Edwards 1983), accounting for up to $40 \%$ of total plant biomass (Fujita et al. 1993) and providing considerable carbohydrate storage for recovery after disturbance. Kudzu vines are capable of rooting from stem nodes to form new plants that rapidly expand the infestation (J. H. Miller and K. V. Miller 1999). Leaf area index ( $\mathrm{LAI}$ ) (square meters of leaf area per square meter of ground area) of kudzu can exceed 8 (Fujita et al. 1993), resulting in dense shade capable of absorbing almost all direct solar radiation incident on a given site. As it switches from a prostrate to a climbing growth habit, kudzu shifts its priority of carbon allocation from growth of primary branches to growth of the main stem (Tsugawa et al. 1992).

Although it thrives best under full-sunlight conditions, kudzu is considered to be moderately tolerant to shade ( $\mathrm{Fu}$ jita et al. 1993). To achieve $90 \%$ of its maximum photo-

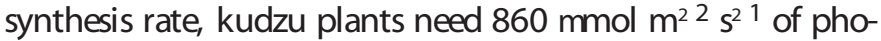
tosynthetic photon - ux density (Carter and Teramura 1988). Kudzu is capable of ${ }^{\circledR}$ xing atmospheric nitrogen to result in whole-plant concentrations of 2.4 to $2.6 \%$ (Fujita et al. 1993). In a shading experiment, kudzu grown at $25 \%$ of incoming solar radiation had similar LAI but only half the total biomass and rates of nitrogen ${ }^{\circledR}$ xation as plants grown in full sun (Fujita et al. 1993). These biomass responses to shading were largely a result of reductions in root weight. Fujita et al. (1993) speculated that kudzu's moderate degree of shade tolerance was partly attributable to its ability to ${ }^{\circledR} \mathrm{X}$ and accumulate nitrogen under partial shade.

Eradication of kudzu has been attempted on a large scale since the 1950s (Everest et al. 1991). Anecdotal evidence suggests that kudzu can be controlled effectively with close grazing from sheep or goats or monthly mowing or tillage but only if such treatments are sustained for 2 successive $y r$ 
TABle 1. Names, application rates, and soil half-lives for five herbicide treatments applied to kudzu-dominated communities. The sixth treatment (not listed) is the nonsprayed check.

\begin{tabular}{|c|c|c|c|c|c|}
\hline \multirow{3}{*}{ Treatment $^{\mathrm{a}}$} & \multicolumn{2}{|c|}{ Herbicide names } & & & \multirow[b]{2}{*}{ Soil half-life ${ }^{\mathrm{d}}$} \\
\hline & Commercial $^{\mathrm{b}}$ & Common & \multicolumn{2}{|c|}{ Herbicide application rates } & \\
\hline & & & $\mathrm{kg} \mathrm{ha}^{-1}$ & units $^{c}$ & d \\
\hline 1 & Transline $^{\circledR}$ & Clopyralid & 0.6 & ae & 40 \\
\hline 2 & Garlon $^{\circledR} 4$ & Triclopyr ester & 3.5 & ae & 30 \\
\hline 3 & Escort $^{\circledR}$ & Metsulfuron & 0.2 & $\mathrm{ai}$ & 30 \\
\hline \multirow[t]{2}{*}{4} & Tordon $^{\circledR} 101 \mathrm{M}$ & Picloram-amine & 0.9 & ae & 90 \\
\hline & & 2,4-D-amine & 3.4 & ae & 10 \\
\hline 5 & Spike ${ }^{\circledR} 20 \mathrm{P}$ & Tebuthiuron & 4.5 & ai & $360-450$ \\
\hline
\end{tabular}

a Treatments 1 to 4 were liquid herbicides mixed in water with $0.25 \%$ concentration of nonionic surfactant (Timberland $90^{\circledR}$ ) and applied with a spray volume of $935 \mathrm{~L} \mathrm{ha}^{-1}$. Treatment 5 was a granular herbicide.

b Transline ${ }^{\circledR}$, Garlon ${ }^{\circledR}$ 4, Tordon ${ }^{\circledR} 101-\mathrm{M}$, and Spike ${ }^{\circledR} 20 \mathrm{P}$ are products of Dow AgroSciences, Inc.; Escort ${ }^{\circledR}$ is a product of the DuPont Corporation.

${ }^{\mathrm{c}}$ Herbicide weight expressed as acid equivalent (ae) or active ingredient (ai).

d Ahrens (1994).

(O’Brien and Skelton 1946). In both methods, frequent defoliation is believed to deplete the root reserves that support the rapid growth rates of kudzu.

Several herbicides are known to provide satisfactory control of kudzu; however, eradication often requires repeated applications for $3 \mathrm{yr}$ or more (Miller 1986). In addition, all kudzu crowns must be treated, or else the spread of surviving plants will reinfest the site. In general, kudzu control was greatest when herbicides were applied in mid to late summer (Dickens and Buchanan 1971; Miller 1986). Among the most effective herbicides for controlling kudzu are picloram and tebuthiuron (Miller 1985), although control can be more difficult in older patches and along patch borders where roots are larger and more herbicide tolerant (Miller and Edwards 1983).

Integrated weed control (IWC) combines two or more methods of suppressing weeds to intensify or extend the duration of control pressure (Anderson 1983). One potential IWC approach is to combine a herbicide treatment with induced competition from an aggressive plant species or "smother crop" (Anderson 1983). Initial screenings have shown that loblolly pine (Pinus taeda L.) can tolerate overthe-top applications of selective herbicides that provide kudzu control (Edwards and Gonzales 1986; Michael 1986). When grown in high-density, uniform stands, loblolly pine can competitively exclude a variety of understory plant species (Schultz 1997). In addition, our field observations suggest that fully stocked stands of loblolly pine can prevent understory kudzu vines from growing upward and overtopping the trees.

In this study, combinations of herbicides and high-density plantings of loblolly pine were applied to kudzu-dominated communities to test potential IWC methods for controlling kudzu. Treatment responses of crown cover, biomass, relative light intensity (RLI), and soil water content (SWC) were evaluated to identify changes in plant community structure and mechanisms of interference among species.

\section{Materials and Methods}

\section{Study Sites and Treatments}

The research was conducted at four sites on the Savannah River Site (SRS), an 80,320-ha National Environmental Research Park near Aiken, SC (33 latitude, $82^{\circ}$ longitude).
On the basis of historic aerial photographs, we concluded that each site was a former pasture or agricultural field before 1950 (USDA Forest Service-Savannah River, unpublished data). At the time of study initiation each site comprised 0.4 to 0.8 ha of relatively uniform coverage of kudzu, occasionally occurring as a drape over scattered individual trees. Soils included loamy, kaolinitic, thermic Arenic Plinthic Kandiudults of the Fuquay series (Burma site); loamy, kaolinitic, thermic Grossarenic Kandiudults of the Troup series (Cloverleaf site); loamy, kaolinitic, thermic Arenic Kanhapludults of the Ailey series or fine, kaolinitic, thermic Plinthic Paleudults of the Varina series (Home site); and a Udorthent fill soil of unknown origin (Reactor site) (Rogers 1990).

Rainfall during the growing season (May to October) on the SRS averages $62.5 \mathrm{~cm}$ (Rogers 1990). Each site (block) was divided into six plots of equal area $(0.07$ to $0.13 \mathrm{ha})$, and one herbicide treatment was randomly assigned to each (Table 1). The five herbicides tested have half-lives that vary from 10 to $450 \mathrm{~d}$ in common agricultural soils. The picloram $+2,4-\mathrm{D}$ treatment is referred to hereafter as the "picloram" treatment. Treatment specifications were those recommended by the herbicide manufacturers. Only the granular formulation of tebuthiuron was registered for the intended use, and it was selected because of its ability to penetrate the dense canopy of kudzu. In the initial herbicide application (early July 1997), liquid herbicides were applied as a broadcast spray with backpack sprayers, and the granular tebuthiuron treatment was broadcasted with a shouldermounted cyclone fertilizer spreader. To provide a uniform application, half the treatment material was applied in one direction, and the other half was applied perpendicular to the first direction. Kudzu-draped pines and hardwoods greater than $1.5 \mathrm{~m}$ in height were cut several weeks before the treatments to enable uniform applications of the herbicides.

In December 1997, each study site was broadcast burned at high intensity (temperatures not measured) to completely consume herbicide-treated or winter-dormant kudzu vines and other fine fuels before planting pines. Herbicide-treatment plots were split, and presence vs. absence of planted loblolly pine was systematically assigned to each half. In the pine-planting half, two subplots ( 10 by $10 \mathrm{~m}$ and 5 by 5 $\mathrm{m}$ in dimension) were randomly located for high-density 
plantings of loblolly pine. In January 1998, 100 loblolly pines were planted at densities of 1 and 4 seedlings $\mathrm{m}^{-2}$ in the large and small subplots, respectively. To control recovering kudzu, the same herbicides were applied in June 1998 and 1999 at the same rate as in 1997. Clopyralid and metsulfuron are considered pine-safe when applied according to product label specifications (Edwards and Gonzales 1986; Kline and Smith 1994); therefore, they were applied as broadcast treatments over the top of the planted pines. The other herbicides were applied as spot treatments directed away from the planted pines. Paraquat herbicide (Gramoxone ${ }^{\circledR}$ Extra, $2.5 \%$ solution in water plus $0.125 \%$ nonionic surfactant ${ }^{1}$ ) was applied monthly during each growing season to eliminate encroaching kudzu vines within a $1-\mathrm{m}$ strip surrounding each plot.

The experimental design of the study was a randomized complete block with a split-plot arrangement of treatments replicated four times, once at each site. The six herbicide treatments were whole plots, and the three pine densities $(0$, 1 , or 4 seedlings $\mathrm{m}^{-2}$ ) were split plots within each whole plot.

\section{Vegetation Responses}

Crown cover (\%) by species or species group was estimated visually within $1-\mathrm{m}^{2}$ square areas centered at each of three systematically located, permanently marked sample points per split plot $(n=216)$. Cover estimates were recorded in June and August 1997, June and August 1998, and August 1999, 2000, and 2001 for each of the following six species groups: kudzu, blackberry, forbs (broadleaved herbaceous species), grasses, planted pines, and other woody species. To predict aboveground biomass $\left(\mathrm{g} \mathrm{m}^{-2}\right)$ of kudzu, blackberry, forbs, and grasses, cover of each species group was assessed in August each year at 4 to 12 additional sample points per site, after which the vegetation was clipped at the soil surface, sorted by species group, placed in paper bags, returned to the laboratory, and dried at $65 \mathrm{C}$ to a constant weight $(\mathrm{g})$. A new set of biomass sample points was selected each year to represent the full range of cover for each species group. For biomass estimation, forbs and grasses were combined into a herbaceous vegetation category. During the 1997, 1998, and 1999 kudzu biomass collections, samples were separated into leaf and stem components. Random samples of 10 to 20 kudzu leaves each were collected from intact vines, stored in an ice chest, and returned to the laboratory for determination of specific leaf area (SLA) (square centimeter of leaf area per gram of dry weight) with a video image analysis system. ${ }^{2}$ A sufficient number of kud$\mathrm{zu}$ leaf samples were collected to enable testing for SLA differences among sample years, herbicide treatments (1997 samples), and pine densities (1998 samples) and between the upper and lower layers of the kudzu canopy in nonsprayed plots (1999 samples). LAI (one sided) of kudzu was calculated by multiplying foliage dry weight from a given sample point by the respective average annual value of SLA.

The 36 interior loblolly pines within each 100-seedling split plot were measured for ground-line stem diameter $(\mathrm{mm})$ and height $(\mathrm{cm})$ immediately after planting and in subsequent dormant seasons $1,2,3$, and 4 yr after planting. During August 1998, 1999, 2000, and 2001, a total of 59 loblolly pines (8 to 23 per year) from interior buffer rows of randomly selected split plots were measured for stem di- ameter and height, severed at the soil surface, and returned to the laboratory, where they were dried at $65 \mathrm{C}$ to a constant weight and weighed $(\mathrm{g})$.

\section{Light and Soil Water}

Light intensity at the soil surface was assessed on August 11, 1998, August 30, 1999, and September 14, 2001, as photosynthetically active radiation (PAR) measured with a sunfleck ceptometer. ${ }^{3}$ These measurement dates corresponded approximately with the period of maximum vegetation development for each growing season. Readings were taken between 9:30 A.M and 3:00 P.M. Eastern Standard Time under clear sky conditions at the same sample points used for estimating crown cover $(n=216)$. At each sample point, PAR was measured both on the ground and above, or immediately adjacent to, the dominant canopy to quantify the percentage of full sunlight reaching the soil surface (RLI).

Rainfall during the 1998 to 2001 growing seasons was monitored at the SRS weather stations closest to each of the four study sites. Volumetric SWC (\%) (0- to 45-cm depth) was assessed by time domain reflectometry. ${ }^{4}$ Measurements were taken monthly during April to October 1998 and May to October 1999 using a pair of stainless steel rods installed permanently near the center of each split plot $(n=72)$. Soil water measurements were delayed at least $24 \mathrm{~h}$ after major rainfall events ( $>25 \mathrm{~mm}$ precipitation).

\section{Statistical Analysis}

All statistical analyses were performed with SAS (SAS 1989). Growing-season averages of SWC were calculated for each combination of site, whole plot, and split plot. Data for each periodic measurement of crown cover, pine survival and size, and RLI also were averaged for each combination of site, whole plot, and split plot. Each variable was subjected to an analysis of variance (ANOVA) for a split-plot design. Before ANOVA, an angular transformation was applied to improve normality of variables expressed as percentages (crown cover, pine survival, RLI, and SWC) (Sokal and Rohlf 1981). A logarithmic transformation was applied to improve normality of pine stem diameter and height. For each ANOVA, residuals were plotted against predicted values of the dependent variable to determine whether residual variances were relatively homogeneous. If the $F$ test in the ANOVA indicated a significant interaction between herbicide treatment and pine density effects, interaction means were presented and multiple comparisons were conducted with Bonferroni-adjusted probabilities (SAS 1989). The only interaction means compared were those among herbicide treatments for a given pine density ( 45 contrasts) and those among pine densities for a given herbicide treatment (18 contrasts). If the interaction $F$ test was not significant but a main-effect $F$ test was significant, main-effect means were presented and multiple comparisons were conducted with Tukey's test (SAS 1989). Unless indicated otherwise, treatment differences described below were significant ( $\mathrm{P} \leq$ $0.05)$.

Linear regression was used to fit the following general Equation 1 for predicting aboveground biomass of each species group or LAI of kudzu using the pooled data from 1997 to 2001: 


$$
\log _{\mathrm{e}}(Y)=B_{0}+B_{1}\left(\log _{\mathrm{e}}(X)\right),
$$

where $Y$ is either kudzu LAI or aboveground biomass of a given species group, and $X$ is either cover (\%) per square meter of kudzu, blackberry, or herbaceous vegetation or stem volume $\left(\mathrm{cm}^{3}\right)$ of a loblolly pine seedling. Pine stem volume was calculated with the formula for a parabola:

$$
V=\pi(D / 20)^{2} \times H / 2
$$

where $V$ is stem volume $\left(\mathrm{cm}^{3}\right), D$ is stem diameter $(\mathrm{mm})$, and $H$ is height $(\mathrm{cm})$. For each species group regression, indicator variables were specified to enable comparisons of slopes and intercepts among the 1997 to 2001 sample years (Sokal and Rohlf 1981). Coefficients were retained in the final models if they were significant $(P \leq 0.05)$.

\section{Results and Discussion}

\section{Vegetation Responses}

\section{Kudzu Cover}

Before the herbicide treatments (June 1997), kudzu cover in the nonsprayed check was less than in the clopyralid and metsulfuron treatments - an unexpected result of treatment randomization (Table 2). Eight weeks after the first herbicide treatment (August 1997), kudzu cover differed among the nonsprayed check (86\%), the tebuthiuron treatment (25\%), and the remaining herbicide treatments (0 to $2 \%$ ). First-year control of kudzu by tebuthiuron was probably limited because the granular formulation was slower to be absorbed in the soil and taken up by the plant than the foliar-applied formulations of the other herbicides. In June 1998, kudzu cover in the clopyralid (9\%) and triclopyr treatments $(9 \%)$ was greater than in the picloram treatment (0\%). In August 1998 and 1999, approximately 8 wk after the second and third herbicide treatments, respectively, kud$\mathrm{zu}$ cover in each of the herbicide treatments was less than in the nonsprayed check. In August 2000 and 2001, kudzu cover increased in the clopyralid treatment, resulting in the following ranking: nonsprayed check $>$ clopyralid $>$ remaining herbicide treatments. In August 2000, kudzu cover in loblolly pine stands planted with 1 seedling $\mathrm{m}^{-2}(5 \%)$ was less than in the absence of pine (9\%). In 2001, differences in kudzu cover among pine densities were of similar magnitude but not statistically significant $(\mathrm{P}=0.123)$. Unfortunately, the study provided only a limited opportunity to test pine density effects on kudzu recovery because only the clopyralid treatment had significant amounts of kudzu cover ( 5 to $15 \%$ cover in 2000 and 2001, respectively) growing in association with a dense canopy of loblolly pine.

Each of the herbicides strongly reduced abundance of kudzu, especially after the 1998 and 1999 applications. Only the clopyralid treatment had strong signs of kudzu recovery during the study (15\% cover by 2001). Despite the high degree of kudzu control provided by repeated herbicide treatments, traces of the vine were present in the most effective treatments at study termination ( 1 to $2 \%$ cover in the triclopyr, metsulfuron, picloram, and tebuthiuron treatments in 2001), and eventual recovery of the species is therefore likely, especially near the nonsprayed check and perimeter of each study site.

\section{Kudzu Leaf Area}

SLA of kudzu in $1998\left(175 \mathrm{~cm}^{2} \mathrm{~g}^{-1}\right) 6$ mo after burning was less than in $1997\left(303 \mathrm{~cm}^{2} \mathrm{~g}^{-1}\right)$ and $1999\left(290 \mathrm{~cm}^{2}\right.$ $\mathrm{g}^{-1}$ ). Values of kudzu SLA did not vary among herbicide treatments or pine densities. The lower layer of foliage in the kudzu canopy had a greater SLA $\left(345 \mathrm{~cm}^{2} \mathrm{~g}^{-1}\right)$ than the upper layer $\left(235 \mathrm{~cm}^{2} \mathrm{~g}^{-1}\right)$.

Regression equations for predicting LAI of kudzu differed among specific sample years probably because of changes in canopy structure as the stand recovered from treatment (Table 3). Predictions of kudzu leaf area for $100 \%$ cover indicated that its LAI at full canopy coverage averaged 4.0, 1.8, and $3.3 \mathrm{~m}^{2} \mathrm{~m}^{-2}$ for 1997,1998 , and 1999 , respectively. These LAI predictions were strongly influenced by both foliage biomass and SLA of the kudzu canopy.

Pretreatment values of SLA and LAI were consistent with those reported for natural populations in Japan (Tsugawa et al. 1993). However, first-year (1998) recovery of kudzu from burning in this study was associated with reductions in SLA and LAI. SLA in 1999 also was lower in the upper than in the lower portion of the canopy. In both instances, full-sun conditions probably stimulated the development of thicker leaf blades with lower SLA values (i.e., less surface area per unit dry weight) (Waring and Schlesinger 1985).

\section{Blackberry}

Blackberry species identified in the treatment plots included highbush blackberry, sand blackberry, and southern dewberry. Blackberry cover did not vary significantly before the herbicide treatments (Table 2). Eight weeks after the herbicide treatments (August 1997), blackberry cover was ranked as follows: clopyralid (29\%) $>$ nonsprayed check and tebuthiuron $(6$ to $9 \%)>$ remaining herbicides $(<1 \%)$. In June 1998 and August 1999, the ranking was clopyralid $>$ nonsprayed check $>$ remaining herbicides. In August 1998, during the first growing season after planting loblolly pine, the interaction of herbicide treatment and pine density was significant for blackberry cover $(\mathrm{P}=0.044)$. Multiple comparisons of means indicated that the interaction was attributable to the greater level of blackberry cover in clopyralid plots than in others plots for a given pine density, with the exception of nonsprayed plots having a pine density of 1 seedling $\mathrm{m}^{-2}$ (Table 4). Because no phytotoxic effects on blackberry were observed from clopyralid, it appears that the species is tolerant of this herbicide. Blackberry cover no longer differed significantly among herbicide treatments in the years after the final herbicide treatment (1999).

In 1999, 2000, and 2001, blackberry cover was less in stands planted with 4 than with 1 pine seedling $\mathrm{m}^{-2}$ (Table 2). The lower abundances of blackberry observed during this time in pine densities of 4 and 0 seedlings $\mathrm{m}^{-2}$ (vs. 1 seedling $\mathrm{m}^{-2}$ ) probably can be attributed to intense competition from planted pines and herbaceous species, respectively (cover responses described below).

\section{Herbaceous Vegetation}

Dominant species of herbaceous vegetation were those typical of old-field succession, including common ragweed (Ambrosia artemisiifolia L.), dogfennel [Eupatorium capillifolium (Lam.) Small], eastern fireweed [Erechtites hieracifolia 


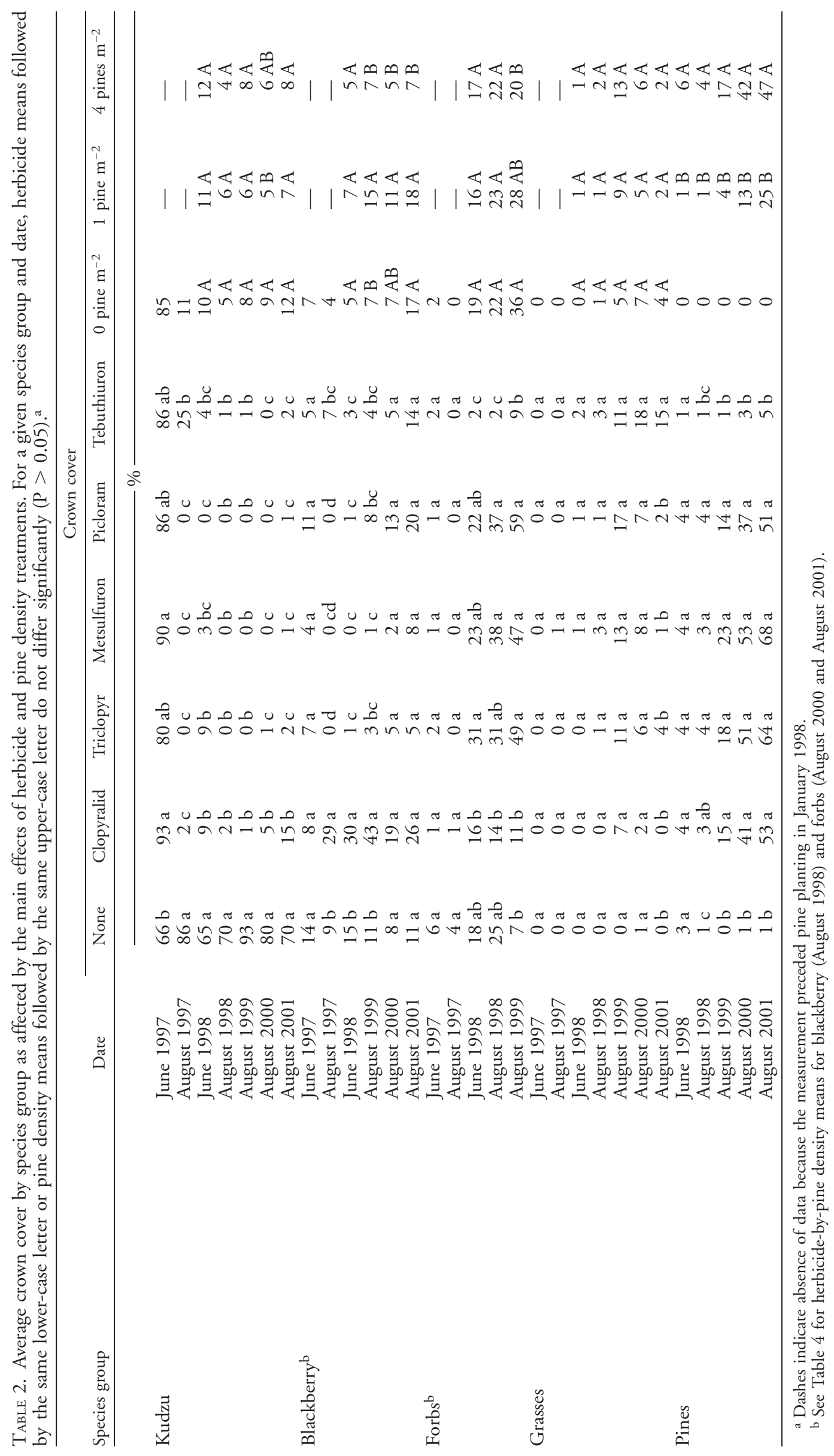

Harrington et al.: Kudzu control • 969 
TABLE 3. Coefficients and goodness-of-fit statistics for regression models used to predict aboveground biomass and leaf area index (LAI) of kudzu and aboveground biomass of blackberry, herbaceous vegetation, and loblolly pine.

\begin{tabular}{|c|c|c|c|c|c|c|c|}
\hline \multirow[b]{2}{*}{ Species group } & \multirow{2}{*}{$\begin{array}{c}\text { Dependent } \\
\text { variable }\end{array}$} & \multirow[b]{2}{*}{ Year } & \multicolumn{2}{|c|}{ Regression coefficients ${ }^{\mathrm{a}}$} & \multicolumn{3}{|c|}{ Fit statistics ${ }^{\mathrm{b}}$} \\
\hline & & & $B_{0}$ & $B_{1}$ & $R^{2}$ & $S_{y \cdot x}$ & $n$ \\
\hline \multirow[t]{6}{*}{ Kudzu } & \multirow[t]{3}{*}{ Biomass $\left(\mathrm{g} \mathrm{m}^{-2}\right)$} & 1998 & 2.122 & 0.788 & \multirow[t]{3}{*}{0.877} & \multirow[t]{3}{*}{0.554} & \multirow[t]{3}{*}{79} \\
\hline & & 1999 & 0.854 & 1.030 & & & \\
\hline & & Otherc & 1.225 & 1.030 & & & \\
\hline & \multirow[t]{3}{*}{ LAI $\left(\mathrm{m}^{2} \mathrm{~m}^{-2}\right)$} & 1997 & -2.416 & 0.823 & \multirow[t]{3}{*}{0.865} & \multirow[t]{3}{*}{0.664} & \multirow[t]{3}{*}{63} \\
\hline & & 1998 & -3.181 & 0.823 & & & \\
\hline & & 1999 & -3.892 & 1.106 & & & \\
\hline \multirow[t]{2}{*}{ Blackberry } & \multirow[t]{2}{*}{ Biomass $\left(\mathrm{g} \mathrm{m}^{-2}\right)$} & 1999 & -0.325 & 1.409 & \multirow[t]{2}{*}{0.797} & \multirow[t]{2}{*}{0.686} & \multirow[t]{2}{*}{54} \\
\hline & & Other & 1.658 & 0.991 & & & \\
\hline \multirow[t]{3}{*}{ Herbaceous vegetation } & \multirow[t]{3}{*}{ Biomass $\left(\mathrm{g} \mathrm{m}^{-2}\right)$} & 1998 & 1.293 & 1.076 & \multirow[t]{3}{*}{0.783} & \multirow[t]{3}{*}{0.633} & \multirow[t]{3}{*}{105} \\
\hline & & 1999 & 1.073 & 1.076 & & & \\
\hline & & Other & 1.993 & 1.076 & & & \\
\hline \multirow[t]{2}{*}{ Pines } & \multirow[t]{2}{*}{ Biomass $\left(\mathrm{g} \mathrm{m}^{-2}\right)$} & 1998 & 0.658 & 0.875 & \multirow[t]{2}{*}{0.979} & \multirow[t]{2}{*}{0.274} & \multirow[t]{2}{*}{59} \\
\hline & & Other & 0.254 & 0.875 & & & \\
\hline
\end{tabular}

a Regression models have the form, $\log _{\mathrm{e}}(Y)=B_{0}+B_{1}\left(\log _{\mathrm{e}}(X)\right)$, where $X$ is either cover (\%) per square meter of kudzu, blackberry, or herbaceous vegetation, or stem volume $\left(\mathrm{cm}^{3}\right)$ of an individual pine seedling.

${ }^{\mathrm{b}}$ Fit statistics represent the regression of combined data from the 1997 to 2001 measurement dates. $R^{2}$ is the coefficient of determination adjusted for degrees of freedom and $S_{y \cdot x}$ is the standard error of estimate.

${ }^{c}$ Regression coefficients for the combined 1997, 2000, and 2001 data usually differed from those for the 1998 or 1999 data.

(L.) Raf. ex DC.], horseweed [Conyza canadensis (L.) Cronq.], and little bluestem [Schizachyrium scoparium (Michx.) Nash].

Forb cover did not vary before the herbicide treatments, and it developed rapidly after herbicidal control of kudzu (Table 2). In June 1998, just before the second herbicide treatment, forb cover differed among the triclopyr (31\%), clopyralid (16\%), and tebuthiuron treatments $(2 \%)$. Forb cover in nonsprayed plots peaked at $25 \%$ in August 1998, before kudzu was able to reestablish its dominance after the December 1997 fire. At its peak development in 1999, forb cover was greater in picloram, triclopyr, and metsulfuron plots than in clopyralid, tebuthiuron, and nonsprayed plots. These differences in forb abundance resulted largely from clopyralid and tebuthiuron phytotoxicity to ragweed (Ahrens 1994). Both herbicides eliminated common ragweed, although the species flourished in the metsulfuron and triclopyr treatments. Also in 1999, forb cover was greater in the absence of pine $(36 \%)$ than in its presence at 4 seedlings $\mathrm{m}^{-2}(20 \%)$.
In 2000 and 2001, the interaction of herbicide treatment and pine density was significant for forb cover $(\mathrm{P}<0.030)$. Multiple comparisons of means indicated that the interaction was attributable to three responses (Table 4): (1) low abundances of forbs in nonsprayed and tebuthiuron plots in the absence of pine, attributable to kudzu competition and residual herbicide effects, respectively, (2) strong reductions in forb cover with increasing pine density in the metsulfuron and triclopyr treatments, attributable to pine competition, which contrasted strongly with the much milder responses to pine density observed in the other herbicide treatments, and (3) greater forb cover in tebuthiuron plots than in clopyralid plots at a pine density of four seedlings $\mathrm{m}^{-2}$, attributable to absence of pine competition in tebuthiuron plots (pine responses described below).

Grass cover was virtually absent before the herbicide treatments (Table 2). Throughout the 1997 to 2000 period, grass cover did not differ among the herbicide treatments. In August 2001, grass cover in tebuthiuron plots (15\%) was greater than in each of the other plots (0 to $4 \%)$. Grass

TABLE 4. Average crown cover of blackberry and forbs (broadleaved herbaceous species) as affected by the interaction of herbicide and pine density treatments. For a given date and pine density, herbicide means followed by the same lowercase letter do not differ significantly $(P>0.05)$. Likewise, for a given date and herbicide, pine density means followed by the same uppercase letter do not differ significantly $(\mathrm{P}>0.05)$.

\begin{tabular}{|c|c|c|c|c|c|c|c|c|}
\hline \multirow[b]{2}{*}{ Species group } & \multirow[b]{2}{*}{ Date } & \multicolumn{7}{|c|}{ Crown cover } \\
\hline & & $\begin{array}{l}\text { Pine } \\
\text { density }\end{array}$ & None & Clopyralid & Triclopyr & Metsulfuron & Picloram & Tebuthiuron \\
\hline \multirow{3}{*}{ Blackberry } & $A_{u}$ onst 1098 & 0 & $6 \mathrm{~b}-\mathrm{A}$ & & & & & \\
\hline & August 19y8 & 1 & $10 \mathrm{ab} A$ & 16 a A & $\begin{array}{l}0 \text { C A } \\
0 \subset \mathrm{A}\end{array}$ & $\begin{array}{l}0 \text { C A } \\
0 \subset \mathrm{A}\end{array}$ & $\begin{array}{l}1 \text { DC } A \\
2 \text { bc A }\end{array}$ & $4 \mathrm{bc} \mathrm{A}$ \\
\hline & & 4 & $4 \mathrm{~b} \mathrm{~A}$ & 31 a $\mathrm{A}$ & $1 \mathrm{~b} \mathrm{~A}$ & $0 \mathrm{~b} \mathrm{~A}$ & $1 \mathrm{~b} \mathrm{~A}$ & $1 \mathrm{~b} \mathrm{~A}$ \\
\hline \multirow[t]{6}{*}{ Forbs } & August 2000 & 0 & $1 \mathrm{c} \mathrm{A}$ & 9 abc $A$ & $40 \mathrm{ab} A$ & 54 a A & 29 abc A & 4 bc A \\
\hline & & 1 & 5 a $A$ & 6 a A & 17 a $A$ & 22 a $A B$ & 36 a $A$ & 10 a $A$ \\
\hline & & 4 & 4 a $A$ & 2 a $A$ & 6 a A & 2 a B & 10 a $A$ & 14 a A \\
\hline & August 2001 & 0 & $4 \mathrm{~b} \mathrm{~A}$ & $22 \mathrm{ab} A$ & 45 a A & 49 a $\mathrm{A}$ & $25 \mathrm{ab} A$ & $6 \mathrm{~b} \mathrm{~A}$ \\
\hline & & 1 & 5 a A & 3 a $\mathrm{A}$ & 7 a B & 12 a $A B$ & 15 a $\mathrm{A}$ & 15 a A \\
\hline & & 4 & $2 \mathrm{ab} A$ & $1 \mathrm{~b} \mathrm{~A}$ & $2 a b B$ & $3 \mathrm{ab} \mathrm{B}$ & $3 a b A$ & 23 a $A$ \\
\hline
\end{tabular}


TABLE 5. Average survival, stem diameter, and height of planted loblolly pines as affected by the main effects of herbicide and pine density treatments. For a given variable and year, herbicide means followed by the same lowercase letter or pine density means followed by the same uppercase letter do not differ significantly $(\mathrm{P}>0.05)$.

\begin{tabular}{|c|c|c|c|c|c|c|c|c|c|}
\hline Variable & Year & None & Clopyralid & Triclopyr & Metsulfuron & Picloram & Tebuthiuron & 1 pine $\mathrm{m}^{-2}$ & 4 pines $\mathrm{m}^{-2}$ \\
\hline \multirow[t]{4}{*}{ Survival (\%) } & 1998 & $41 \mathrm{~b}$ & $81 \mathrm{a}$ & $90 \mathrm{a}$ & $86 a$ & $89 a$ & $21 \mathrm{~b}$ & $72 \mathrm{~A}$ & $68 \mathrm{~A}$ \\
\hline & 1999 & $19 \mathrm{~b}$ & $78 \mathrm{a}$ & $81 \mathrm{a}$ & $82 \mathrm{a}$ & $76 \mathrm{a}$ & $13 \mathrm{~b}$ & $61 \mathrm{~A}$ & $56 \mathrm{~A}$ \\
\hline & 2000 & $14 \mathrm{~b}$ & $78 \mathrm{a}$ & $79 a$ & $79 a$ & $75 a$ & $8 \mathrm{~b}$ & $57 \mathrm{~A}$ & $52 \mathrm{~A}$ \\
\hline & 2001 & $9 \mathrm{~b}$ & $72 \mathrm{a}$ & $76 \mathrm{a}$ & $75 \mathrm{a}$ & $73 \mathrm{a}$ & $8 \mathrm{~b}$ & $54 \mathrm{~A}$ & $47 \mathrm{~A}$ \\
\hline \multirow[t]{5}{*}{ Stem diameter $(\mathrm{mm})$} & 1997 & $5 \mathrm{a}$ & $5 a$ & $5 a$ & $5 a$ & $5 a$ & $5 a$ & $5 \mathrm{~A}$ & $5 \mathrm{~A}$ \\
\hline & 1998 & $6 \mathrm{a}$ & $7 a$ & $8 \mathrm{a}$ & $9 \mathrm{a}$ & $8 \mathrm{a}$ & $8 \mathrm{a}$ & $8 \mathrm{~A}$ & $7 \mathrm{~A}$ \\
\hline & 1999 & $10 \mathrm{~b}$ & $15 \mathrm{a}$ & $16 \mathrm{a}$ & $19 a$ & $15 \mathrm{a}$ & $11 \mathrm{~b}$ & $14 \mathrm{~A}$ & $14 \mathrm{~A}$ \\
\hline & 2000 & $21 \mathrm{~b}$ & $33 a$ & $36 a$ & $41 \mathrm{a}$ & $34 \mathrm{a}$ & $24 \mathrm{~b}$ & $34 \mathrm{~A}$ & $30 \mathrm{~A}$ \\
\hline & 2001 & $28 \mathrm{~b}$ & $41 \mathrm{a}$ & $42 a$ & $48 \mathrm{a}$ & $41 \mathrm{a}$ & $31 \mathrm{~b}$ & $43 \mathrm{~A}$ & $35 \mathrm{~A}$ \\
\hline \multirow[t]{5}{*}{ Height $(\mathrm{cm})$} & 1997 & $32 \mathrm{a}$ & $34 \mathrm{a}$ & $33 a$ & $33 a$ & $33 a$ & $32 \mathrm{a}$ & $33 \mathrm{~A}$ & $33 \mathrm{~A}$ \\
\hline & 1998 & $44 \mathrm{a}$ & $49 a$ & $50 a$ & $51 \mathrm{a}$ & $49 a$ & $44 \mathrm{a}$ & $48 \mathrm{~A}$ & $48 \mathrm{~A}$ \\
\hline & 1999 & $52 \mathrm{~b}$ & $96 \mathrm{a}$ & $95 \mathrm{a}$ & $103 a$ & $97 \mathrm{a}$ & $59 \mathrm{~b}$ & $81 \mathrm{~A}$ & $82 \mathrm{~A}$ \\
\hline & 2000 & $84 \mathrm{~b}$ & $172 \mathrm{a}$ & $177 \mathrm{a}$ & $194 \mathrm{a}$ & $167 \mathrm{a}$ & $102 \mathrm{~b}$ & $150 \mathrm{~A}$ & $147 \mathrm{~A}$ \\
\hline & 2001 & $124 \mathrm{~b}$ & $284 \mathrm{a}$ & $309 a$ & $334 \mathrm{a}$ & $285 a$ & $175 \mathrm{~b}$ & $270 \mathrm{~A}$ & $237 \mathrm{~A}$ \\
\hline
\end{tabular}

cover did not vary significantly among the three pine densities for any of the measurements.

\section{Loblolly Pine}

Beginning the first year after planting (1998) and continuing for the duration of the study, pine survival was less in nonsprayed and tebuthiuron plots than in the other plots (Table 5). At the end of 2001, only 8 to $9 \%$ of the trees survived in nonsprayed and tebuthiuron plots compared with 72 to $76 \%$ in the other plots. In 1999, 2000, and 2001 , average stem diameter and height of pines in nonsprayed and tebuthiuron plots were less than those in the other treatments. Planting density did not have a detectable influence on either survival ( $\mathrm{P} \geq 0.208)$ or average size ( $\mathrm{P}$ $\geq 0.077$ ) of pines.

In June 1998, 6 mo after planting, pine cover did not differ among herbicide treatments (Table 2). Eight weeks later (August), pine cover in triclopyr, metsulfuron, and picloram plots (3 to $4 \%$ ) exceeded that of nonsprayed and tebuthiuron plots $(\leq 1 \%)$. In 1999, 2000, and 2001, pine cover in tebuthiuron and nonsprayed plots was less than that observed in the other herbicide plots. At study termination (2001), pine cover ranged from 51 to $68 \%$ in the clopyralid, triclopyr, metsulfuron, and picloram plots, whereas it averaged 1 and $5 \%$ in the nonsprayed and tebuthiuron plots, respectively. For the duration of the study, pine cover was greater in stands planted with 4 than with 1 seedling $\mathrm{m}^{-2}$, with absolute differences reaching their maximum in 2000 .

\section{Other Woody Species}

Other woody species present in the study plots included the vines: Japanese honeysuckle (Lonicera japonica Thunb.), poison ivy [Toxicodendron radicans (L.) Kuntze], Smilax spp., and yellow jessamine (Gelsemium sempervirens St.-Hil.); the shrubs: chickasaw plum (Prunus angustifolia Marsh.), Chinese privet (Ligustrum sinense Lour.), and winged sumac (Rhus copallinum L.); and the trees: black cherry (Prunus serotina Ehrhart), Chinaberry (Melia azedarach L.), sassafrass [Sassafrass albidum (Nuttall) Nees.], and water oak (Quercus nigra L.). In combination, total cover of these species averaged less than $3 \%$ for each of the measurement dates, and it did not vary among herbicide treatments, pine densities, or their interaction $(P \geq 0.07)$.

\section{Aboveground Biomass}

Regression equations for predicting aboveground biomass of each species group explained 78 to $98 \%$ of the variation in the natural logarithm of aboveground biomass (Table 3). Regression coefficients for 1998 and 1999 sometimes differed from those estimated for the combined 1997, 2000, and 2001 data. For kudzu, reductions in some of the coefficients for 1998 and 1999 compared with the other years probably are attributable to consumption of older stem and branch biomass by the December 1997 fire, resulting in less aboveground biomass per unit of cover.

With the exception of nonsprayed and tebuthiuron plots, aboveground biomass of pine in 2001 outweighed the total contributions of the other species groups combined (Table $6)$. The greatest pine biomass accumulation occurred in metsulfuron plots (20.4 $\mathrm{Mg} \mathrm{ha}^{-1}$ ) — about 20 times that observed in the nonsprayed and tebuthiuron plots $(0.7$ and $1.1 \mathrm{Mg} \mathrm{ha}^{-1}$, respectively). At its greatest posttreatment development, kudzu biomass accumulated $2.5 \mathrm{Mg} \mathrm{ha}^{-1}$ in nonsprayed plots. Increasing loblolly pine density from 1 to 4 seedlings $\mathrm{m}^{-2}$ almost doubled its biomass in 2001. Increases in pine density from 0 to 4 seedlings $\mathrm{m}^{-2}$ were associated with 33,56 , and $67 \%$ reductions in biomass of kudzu, blackberry, and herbaceous vegetation, respectively.

\section{Light and Soil Water}

RLI declined rapidly in the $4 \mathrm{yr}$ of the study because kudzu, blackberry, herbaceous vegetation, or planted pines occupied the available growing space (Table 7). In each measurement year, RLI was greater in tebuthiuron plots than in other plots because this herbicide virtually eliminated all vegetation and maintained these conditions through its persistence in the soil (Ahrens 1994). In 1998 and 1999, dense kudzu cover in nonsprayed plots caused RLI to be less than that in most of the herbicide-treated plots. In 1999, RLI was less in split plots with 4 than with 0 pine seedlings $\mathrm{m}^{-2}$, whereas in 2001 it was less in the presence than in the absence of pine. 
TABLE 6. Average aboveground biomass predicted by species group in 2001 as affected by the main effects of herbicide and pine density treatments. Relative differences $(P \leq 0.05)$ among treatments are identical to those reported for crown cover in Tables 2 and 4 .

\begin{tabular}{|c|c|c|c|c|c|c|c|c|c|}
\hline \multirow[b]{2}{*}{ Species group } & \multicolumn{9}{|c|}{ Aboveground biomass } \\
\hline & None & Clopyralid & Triclopyr & Metsulfuron & Picloram & Tebuthiuron & 0 pine $\mathrm{m}^{-2}$ & 1 pine $\mathrm{m}^{-2}$ & 4 pines $\mathrm{m}^{-2}$ \\
\hline & & & & & $-\mathrm{Mg}$ & $a^{-1}$ & & & \\
\hline Kudzu & 2.5 & 0.6 & 0.2 & 0.1 & 0.1 & 0.2 & 0.6 & 0.4 & 0.4 \\
\hline Blackberry & 0.7 & 1.3 & 0.4 & 0.6 & 1.1 & 0.8 & 0.9 & 1.0 & 0.4 \\
\hline Forbs & 0.6 & 0.7 & 1.3 & 1.6 & 1.2 & 1.3 & 2.1 & 0.9 & 0.5 \\
\hline Grasses & 0.0 & 0.1 & 0.7 & 0.3 & 0.4 & 1.5 & 0.6 & 0.4 & 0.4 \\
\hline Pines & 0.7 & 14.2 & 18.3 & 20.4 & 14.2 & 1.1 & 0.0 & 5.4 & 9.8 \\
\hline
\end{tabular}

Average values of growing season (May to October) rainfall in $1998(64.2 \mathrm{~cm})$ and $1999(63.8 \mathrm{~cm})$ were slightly greater than the long-term (1964 to 1985) average (62.5 $\mathrm{cm}$; Rogers 1990), whereas those for $2000(58.4 \mathrm{~cm})$ and $2001(60.9 \mathrm{~cm})$ were slightly less.

Effects of the herbicide treatments on SWC were not as discrete as those found for RLI. In 1998, SWC did not differ significantly among herbicide treatments or pine densities ( $P \geq 0.159$; data not shown). However, in 1999 the interaction of herbicide treatment and pine density effects was significant $(P=0.042)$. Multiple comparisons of means indicated that in the absence of pine, SWC was greater in tebuthiuron than in clopyralid plots (Table 8). Tebuthiuron strongly reduced overall vegetation abundance $(26 \%$ vs. 77 to $111 \%$ total cover in the other treatments; Table 2), resulting in higher average values of SWC.

\section{Treatment Implications for Kudzu-Dominated Communities}

In this study, disturbance characteristics of the treatments (e.g., effects of burning and differences in herbicide selectivity and persistence) and subsequent interference among dominant species resulted in the development of four distinctly different plant communities, including those dominated by kudzu (nonsprayed plots), blackberry (clopyralid plots), and forbs (triclopyr, metsulfuron, or picloram plots) and those with low vegetation abundance (tebuthiuron plots).

In nonsprayed plots, burning stimulated vigorous sprouting of kudzu (65\% cover 6 mo after burning), a brief flush of forbs, and eventual reclamation of all growing space by kudzu. High-density plantings of pines had no impact on the structure of this community because the kudzu was able to overtop, suppress, and ultimately kill over $90 \%$ of planted seedlings.

Clopyralid had no detectable phytotoxic effect on blackberry, but it caused a high degree of initial control of kudzu and forbs. As a result of this herbicide selectivity, blackberry became the dominant species in this treatment for the duration of the study. This dominance shifted, however, as high-density plantings of loblolly pine caused competitive exclusion of blackberry. By study termination (2001), recovering kudzu in the clopyralid treatment had begun to climb onto both the blackberry and the pines, foreshadowing its ultimate return to dominance.

The herbicide treatments that effectively controlled kud$\mathrm{zu}$, blackberry, and other woody species without prolonged soil persistence (triclopyr, metsulfuron, and picloram) stimulated the development of a forb-dominated community. Forb cover in these treatments peaked in 1999 at 47 to $59 \%$. In the same year, however, high-density plantings of loblolly pine were beginning to exclude forbs.

Tebuthiuron, which is strongly phytotoxic to broadleaved species and has a high degree of soil persistence (Ahrens 1994), greatly reduced the abundance or virtually eliminated most plant species. Although first-year control of kudzu by tebuthiuron was weak because of delayed activity from this granular, soil-active herbicide, ultimately a high degree of kudzu control was achieved. Very few planted pines survived this treatment, and those that survived were severely stunted. By 2001, grass abundance in tebuthiuron plots exceeded that in other plots. Grasses are known to tolerate growthregulator herbicides like tebuthiuron (Ahrens 1994). Despite the high degree of phytotoxicity and soil persistence of tebuthiuron, some recovery of forbs and blackberries was evident in this treatment by 2001 .

The dominant species in each plant community quickly captured the growing space made available by the herbicide and burning treatments. Success depended on the species' ability to overtop and ultimately suppress other plant species and not on its ability to deplete soil water supplies. For example, recovering kudzu vines in nonsprayed plots quickly encroached on and overtopped other plant species, reducing RLI to $15 \%$ in the first year of the study. However, SWC did not differ among kudzu-, blackberry-, or forb-dominat-

TABLE 7. Average relative intensities of photosynthetically active radiation as affected by the main effects of herbicide and pine density treatments. For a given date, herbicide means followed by the same lowercase letter or pine density means followed by the same uppercase letter do not differ significantly $(\mathrm{P}>0.05)$.

\begin{tabular}{|c|c|c|c|c|c|c|c|c|c|}
\hline \multirow[b]{2}{*}{ Date } & \multicolumn{9}{|c|}{ Relative light intensity } \\
\hline & None & Clopyralid & Triclopyr & Metsulfuron & Picloram & Tebuthiuron & 0 pine $\mathrm{m}^{-2}$ & 1 pine $\mathrm{m}^{-2}$ & 4 pines $\mathrm{m}^{-2}$ \\
\hline & & & & & & & & & \\
\hline August 11, 1998 & $15 \mathrm{c}$ & $34 \mathrm{~b}$ & $43 \mathrm{~b}$ & $36 \mathrm{~b}$ & $39 \mathrm{~b}$ & $76 \mathrm{a}$ & $46 \mathrm{~A}$ & $36 \mathrm{~A}$ & $38 \mathrm{~A}$ \\
\hline August 30, 1999 & $7 \mathrm{c}$ & $19 \mathrm{bc}$ & $24 \mathrm{~b}$ & $20 \mathrm{bc}$ & $24 \mathrm{~b}$ & $63 a$ & $34 \mathrm{~A}$ & $25 \mathrm{AB}$ & $17 \mathrm{~B}$ \\
\hline September 14, 2001 & $4 \mathrm{~b}$ & $5 \mathrm{~b}$ & $7 \mathrm{~b}$ & $6 \mathrm{~b}$ & $8 \mathrm{~b}$ & $27 \mathrm{a}$ & $14 \mathrm{~A}$ & $7 \mathrm{~B}$ & $5 \mathrm{~B}$ \\
\hline
\end{tabular}


TABLE 8. Average soil water content in 1999 as affected by the interaction of herbicide and pine density treatments. For a given pine density, herbicide means followed by the same lowercase letter do not differ significantly $(\mathrm{P}>0.05)$. Likewise, for a given herbicide, pine density means followed by the same uppercase letter do not differ significantly $(\mathrm{P}>0.05)$.

\begin{tabular}{|c|c|c|c|c|c|c|}
\hline \multirow[b]{2}{*}{ Pine density } & \multicolumn{6}{|c|}{ Soil water content } \\
\hline & None & Clopyralid & Triclopyr & Metsulfuron & Picloram & Tebuthiuron \\
\hline \multicolumn{7}{|l|}{ No. $m^{-2}$} \\
\hline 0 & $13 \mathrm{ab} \mathrm{A}$ & $11 \mathrm{~b} \mathrm{~A}$ & $12 \mathrm{ab} A$ & $13 \mathrm{ab} A$ & $16 \mathrm{ab} A$ & 17 a $\mathrm{A}$ \\
\hline 1 & 14 a A & 15 a $\mathrm{A}$ & 13 a $\mathrm{A}$ & 12 a $\mathrm{A}$ & 14 a A & 15 a $\mathrm{A}$ \\
\hline 4 & 13 a A & 15 a $\mathrm{A}$ & 16 a A & 11 a $\mathrm{A}$ & 15 a A & 15 a $\mathrm{A}$ \\
\hline
\end{tabular}

ed communities. Similarly, with increasing planting density of loblolly pine, RLI declined by up to $50 \%$, but SWC did not vary in a consistent pattern. These results indicate that light is the primary factor mediating interference among species in kudzu-dominated communities. Because of its moderate shade tolerance, kudzu will ultimately reclaim its dominance in each of the plant communities if it is able to encroach upon the overtopping species through canopy gaps. An integrated strategy that combines sustained weed control with interference from an overtopping, uniformlydense, smother crop may hold promise for containing the spread of kudzu.

\section{Sources of Materials}

1 Timberland $90^{\circledR}$, non-ionic surfactant, UAP Timberland LLC, 140 Arkansas Street, Monticello, AR 71657.

${ }^{2} \mathrm{AgVision}$, video image analysis system, Decagon Devices, Inc, 950 NE Nelson Ct., Pullman, WA 99163.

3 Sunfleck linear PAR ceptometer, model SF-80, Decagon Devices, Inc., 950 NE Nelson Ct., Pullman, WA 99163.

${ }^{4}$ TRASE model 6050, time domain reflectometry sensor, SoilMoisture Equipment Corp., 801 S. Kellogg Avenue, Goleta, CA 93117.

\section{Acknowledgments}

This research was funded by the USDA Forest Service, Southern Region, Forest Health Protection, under Participating Agreement 08-97-S\&PF-PA-05, and the Department of Energy, Savannah River Operations Office, through USDA Forest Service-Savannah River Interagency Agreement DE-AI09-765SR00056. We especially appreciate the assistance of technical staff, who are too numerous to mention here, and their contributions to plot establishment and maintenance and field and laboratory data collection. We also thank J. Blake and J. Scott for their logistical support and J. Miller, A. Ezell, K. Britton, and D. Marshall for manuscript reviews. In addition, we thank the Dow AgroSciences and DuPont Corporations for providing technical advice and donating herbicides.

The use of trade or firm names in this publication is for reader information and does not imply endorsement of any product or service by the U.S. Department of Agriculture. This publication reports research involving pesticides. It does not contain recommendations for their use, nor does it imply that the uses discussed here have been registered. All uses of pesticides must be registered by appropriate state or federal agencies, or both, before they can be recommended. Caution: Pesticides can be injurious to humans, domestic and wild animals, and desirable plants if they are not handled or applied properly. Use all pesticides selectively and carefully. Follow recommended practices for the disposal of surplus pesticides and pesticide containers.

\section{Literature Cited}

Ahrens, W. H., ed. 1994. Herbicide Handbook. 7th ed. Champaign, IL: Weed Science Society of America. Pp. 66-68, 77-81, 203-205, 235238, 276-278, 292-294.

Anderson, W. P. 1983. Weed Science: Principles. 2nd ed. St. Paul, MN: West. Pp. 65, 71.

Bailey, R. Y. 1939. Kudzu for Erosion Control in the Southeast. Washington, DC: USDA Farmer's Bulletin No. 1840. 31 p.

Carter, G. A. and A. H. Teramura. 1988. Vine photosynthesis and relationships to climbing mechanics in a forest understory. Am. J. Bot. 75:1011-1018.

Corley, R. N., A. Woldeghebriel, and M. R. Murphy. 1997. Evaluation of the nutritive value of kudzu (Pueraria lobata) as a feed for ruminants. Anim. Feed Sci. Technol. 68:183-188.

Dickens, R. and G. A. Buchanan. 1971. Influence of time of herbicide application on control of kudzu. Weed Sci. 19:669-671.

Edwards, M. B. and F. E. Gonzales. 1986. Forestry herbicide control of kudzu and Japanese honeysuckle in loblolly pine sites in central Georgia. Proc. South. Weed Sci. Soc. 39:272-275.

Everest, J. W., J. H. Miller, D. M. Ball, and M. G. Patterson. 1991. Kudzu in Alabama: History, Uses, and Control. Auburn, AL: Alabama Cooperative Extension Service. Circular ANR-65. 8 p.

Fujita, K., K. Matsumoto, G. K. Ofosu-Budu, and S. Ogata. 1993. Effect of shading on growth and dinitrogen fixation of kudzu and tropical pasture legumes. Soil Sci. Plant Nutr. 39:43-54.

Kline, W. N. and A. E. Smith. 1994. Transline ${ }^{\circledR}$ herbicide, a new pine tolerant product for kudzu control. Proc. South. Weed Sci. Soc. 47: 118.

Michael, J. L. 1986. Pine regeneration with simultaneous control of kudzu. Proc. South. Weed Sci. Soc. 39:282-288.

Miller, J. H. 1985. Testing herbicides for kudzu eradication on a Piedmont site. South. J. Appl. For. 9:128-132.

Miller, J. H. 1986. Kudzu eradication trials testing fifteen herbicides. Proc. South. Weed Sci. Soc. 39:276-281.

Miller, J. H. 1988. Kudzu eradication trials with new herbicides. Proc. South. Weed Sci. Soc. 41:220-225.

Miller, J. H. and M. B. Edwards. 1983. Kudzu: where did it come from? And how can we stop it? South. J. Appl. For. 7:165-168.

Miller, J. H. and K. V. Miller. 1999. Forest Plants of the Southeast and Their Wildlife Uses. Champaign, IL: Southern Weed Science Society. Pp. 284-285.

Mitich, L. W. 2000. Intriguing world of weeds: kudzu (Pueraria lobata [Wild.] Ohwi.). Weed Technol. 14:231-235.

O'Brien, R. E. and D. W. Skelton. 1946. The production and utilization of kudzu. Miss. State Coll. Agric. Exp. Stn. Bull. 438:25.

Putz, F. E. 1991. Silvicultural effects of lianas. Pages 493-501 in F. E. Putz and H. A. Mooney, eds. The Biology of Vines. Cambridge, Great Britain: Cambridge University Press.

Rogers, V. A. 1990. Soil Survey of Savannah River Plant Area, Parts of Aiken, Barnwell, and Allendale Counties, South Carolina. Washington, DC: USDA Soil Conservation Service. 127 p., 46 lvs.

[SAS] Statistical Analysis Systems. 1989. SAS/STAT User's Guide. Version 6, Volume 2, 4th ed. Cary, NC: Statistical Analysis Systems Institute. Pp. 913-917, 941-945.

Schultz, R. P. 1997. Loblolly Pine: The Ecology and Culture of Loblolly Pine (Pinus taeda L.). USDA Forest Service, Agriculture Handbook 713. Chapter 9. Washington, DC: USDA Forest Service, Pp. 14-18.

Sokal, R. R. and J. F. Rohlf. 1981. Biometry. 2nd ed. San Francisco: W. H. Freeman. Pp. 245, 427, 499-509.

Tsugawa, H., N. Kawasaki, T. W. Sasek, T. Takahashi, K. Yamamoto, and 
K. Nishikawa. 1993. Dry matter production and leaf area expansion of the current year's canopy in a natural kudzu (Pueraria lobata Ohwi) stand, established in a field left abandoned for about 15 years. J. Jpn. Soc. Grassl. Sci. 38:440-452.

Tsugawa, H., T. Shimizu, T. W. Sasek, and K. Nishikawa. 1992. The climbing strategy of the kudzu-vine (Pueraria lobata Ohwi). Sci. Rep. Fac. Agric. Kobe Univ. 20:1-6. van der Maesen, L.J.G. 1985. Revision of the Genus Pueraria DC. with Some Notes on Teyleria backer (Leguminosae). Wageningen, The Netherlands: Agriculture University Wageningen Papers. 132 p.

Waring, R. H. and W. H. Schlesinger. 1985. Forest Ecosystems: Concepts and Management. New York: Academic. P. 11.

Received October 4, 2002, and approved April 2, 2003. 